Atmos. Chem. Phys., 13, 2723-2733, 2013

www.atmos-chem-phys.net/13/2723/2013/

doi:10.5194/acp-13-2723-2013

(c) Author(s) 2013. CC Attribution 3.0 License.

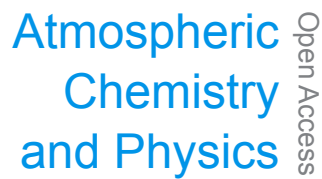

\title{
Sensitivity of cloud condensation nuclei to regional changes in dimethyl-sulphide emissions
}

\author{
M. T. Woodhouse ${ }^{1}$, G. W. Mann ${ }^{1,2}$, K. S. Carslaw ${ }^{1}$, and O. Boucher ${ }^{3, *}$ \\ ${ }^{1}$ Institute for Climate and Atmospheric Science, School of Earth and Environment, University of Leeds, Leeds, LS2 9JT, UK \\ ${ }^{2}$ National Centre for Atmospheric Science, University of Leeds, Leeds, LS2 9JT, UK \\ ${ }^{3}$ Met Office Hadley Centre, FitzRoy Road, Exeter, Devon, EX1 3PB, UK \\ * now at: Laboratoire de Météorologie Dynamique, Centre National de la Recherche Scientifique/Université Pierre et Marie \\ Curie, 4 place Jussieu, 75252, Paris, France
}

Correspondence to: M. T. Woodhouse (m.woodhouse@ see.leeds.ac.uk)

Received: 27 July 2012 - Published in Atmos. Chem. Phys. Discuss.: 18 October 2012

Revised: 13 February 2013 - Accepted: 26 February 2013 - Published: 8 March 2013

\begin{abstract}
The atmospheric oxidation of dimethyl-sulphide (DMS) derived from marine phytoplankton is a significant source of marine sulphate aerosol. DMS has been proposed to regulate climate via changes in cloud properties, though recent studies have shown that present-day global cloud condensation nuclei $(\mathrm{CCN})$ concentrations have only a weak dependence on the total emission flux of DMS. Here, we use a global aerosol microphysics model to examine how efficiently CCN are produced when DMS emissions are changed in different marine regions. We find that global $\mathrm{CCN}$ production per unit mass of sulphur emitted varies by more than a factor of 20 depending on where the change in oceanic DMS emission flux is applied. The variation in $\mathrm{CCN}$ production efficiency depends upon where $\mathrm{CCN}$ production processes (DMS oxidation, $\mathrm{SO}_{2}$ oxidation, nucleation and growth) are most efficient and removal processes (deposition) least efficient. The analysis shows that the production of aerosol sulphate through aqueous-phase oxidation of $\mathrm{SO}_{2}$ limits the amount of $\mathrm{H}_{2} \mathrm{SO}_{4}$ available for nucleation and condensational growth and therefore suppresses $\mathrm{CCN}$ formation, leading to the weak response of CCN to changes in DMS emission. Our results show that past and future changes in the spatial distribution of DMS emissions (through changes in the phytoplankton population or wind speed patterns) could exert a stronger control on climate than net increases in biological productivity.
\end{abstract}

\section{Introduction}

Dimethyl-sulphide (DMS) is a climate-relevant trace gas produced in the surface oceans by some species of phytoplankton (Stefels et al., 2007). Some DMS is vented to the atmosphere by gas transfer processes (e.g. Liss et al., 1997), where it is oxidized (Barnes et al., 2006). The oxidation products of DMS can contribute to atmospheric aerosol, either leading to formation of new particles, or grow existing particles. Observations (Andreae et al., 1999; O’Dowd et al., 1999b; Yang et al., 2011) have shown that aqueous-phase oxidation is the dominant sulphate production mechanism in marine stratocumulus regions.

Surface ocean DMS concentrations are highly variable with season and location. Concentrations range from $<0.1$ to $>50.0 \mathrm{nM}$, the highest concentrations occurring in the highlatitude oceans during summer. Annual mean DMS concentrations from the Kettle and Andreae (2000) observational climatology are on the order of a few nanomols, and are shown in Fig. 1. Sea-surface DMS concentrations have been observed to increase by $8.5 \mathrm{nM}$ in response to iron addition experiments (Boyd et al., 2007), but such changes are shortlived and affect only a small area. Vallina et al. (2007) found that sea-surface DMS concentrations increased locally by up to $0.5 \mathrm{nM}$ in response to a global warming scenario with a marine ecosystem model.

The global sea-air flux of DMS has been estimated to be between 13 and $37 \mathrm{Tga}^{-1}$ sulphur (Kettle and Andreae, 2000). Chin and Jacob (1996) found that DMS accounts for

Published by Copernicus Publications on behalf of the European Geosciences Union. 

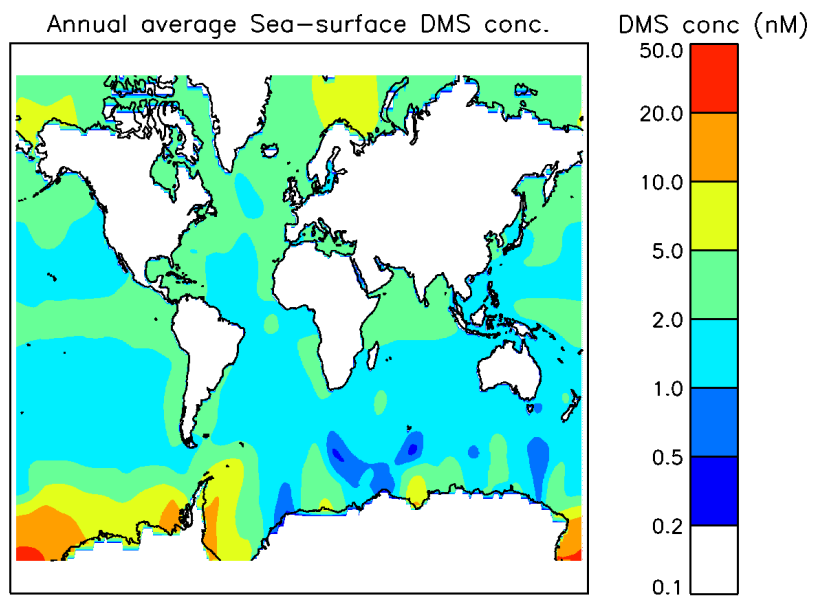

Fig. 1. Annual mean sea-surface DMS concentrations from the Kettle and Andreae (2000) observational climatology.

$20-80 \%$ of non sea-salt sulphate near the surface over the Northern Hemisphere oceans and more than $80 \%$ in most of the Southern Hemisphere.

In what is now known as the CLAW hypothesis, Charlson et al. (1987) suggested that changes in phytoplanktonderived DMS arising from climate change could impact the number of cloud condensation nuclei $(\mathrm{CCN})$ and hence alter cloud optical properties through the first (cloud albedo, Twomey, 1974) and second (cloud lifetime, Albrecht, 1989) aerosol indirect effects. A feedback may then operate that links climate change to cloud albedo. The direction (positive or negative) of the CLAW feedback is not certain however (Ayers and Cainey, 2007; Carslaw et al., 2010).

Estimates of the potential magnitude of the CLAW feedback include Gabric et al. (2001) who predicted an increase in DMS flux of 1-6\% in the mid-latitude southern oceans from a climate-change scenario, resulting in a radiative effect of $-0.3 \mathrm{~W} \mathrm{~m}^{-2}$. From a $\mathrm{CO}_{2}$ doubling experiment in a coupled ocean-atmosphere general circulation model (GCM), Bopp et al. (2004) calculated a $3 \%$ increase in global mean DMS flux leading to a global mean (empirically calculated) radiative effect of $-0.05 \mathrm{~W} \mathrm{~m}^{-2}$. Local changes up to $-1.5 \mathrm{~W} \mathrm{~m}^{-2}$ were simulated in the mid-latitude southern oceans. A more recent estimate by Gunson et al. (2006) found a radiative effect of $-1.8 \mathrm{Wm}^{-2}$ from a doubling of DMS flux. In a modal microphysical aerosol scheme in a GCM nudged by reanalysis meteorology, by switching off oceanic DMS emission, Thomas et al. (2010) found that the contribution of DMS-derived cloud droplet number (CDN) to radiative effect was $-2.0 \mathrm{~W} \mathrm{~m}^{-2}$. Although these studies demonstrate a significant radiative effect from DMS, this does not necessarily translate to a signficant CLAW feedback. Current thinking (Woodhouse et al., 2010; Quinn and Bates, 2011) suggests that the CLAW feedback is very weak and not relevant within the present-day climate system.
Wind speed is an important control of DMS flux due to the non-linear (power) relationship between flux and wind speed (e.g. Nightingale et al., 2000). Wind speed is also an important factor in determining mixed layer depth (Mellor and Durbin, 1975), which has been shown by Vallina and Simó (2007) to have a strong connection to sea-surface DMS concentration, acting through sunlight penetration and nutrient availability. Compiled observational data from the mid19th century to present-day suggests that alterations in atmospheric circulation are occurring (Trenberth et al., 2007). For instance, storm tracks have moved poleward, with an increase in intensity but decrease in total number of storms. Increases in wind speed in the tropical North Atlantic and extra-tropical North Pacific, and decreases in the equatorial Atlantic, tropical South Atlantic, and subtropical North Pacific have been observed. Mid-latitude westerlies are also observed to have changed in both hemispheres (Trenberth et al., 2007). Using satellite measurements, Young et al. (2011) found an increase in global wind speeds. Korhonen et al. (2010) showed that an increase in wind speed of $0.45 \pm 0.2 \mathrm{~m} \mathrm{~s}^{-1}$ decade $^{-1}$ at $50-65^{\circ} \mathrm{S}$ since the early 1980 's caused a $22 \%$ increase in $\mathrm{CCN}$ concentrations at these latitudes. They calculated that locally up to $33 \%$ of $\mathrm{CCN}$ changes due to changes in wind speed could be due to higher DMS fluxes, with the rest being due to changes in sea-spray.

A recent geoengineering suggestion (Wingenter et al., 2007) proposed that by artificially increasing the sea-surface concentration of DMS and thereby increasing the number of $\mathrm{CCN}$, a climate cooling effect related to the first aerosol indirect effect (Twomey, 1974) could be achieved. The impact on $\mathrm{CCN}$ of this suggestion was modelled by Woodhouse et al. (2008), and found to be much lower than anticipated by Wingenter et al. (2007).

The response of global CCN to changes in DMS has been studied in models. Korhonen et al. (2008) used the sectional microphysical aerosol scheme GLOMAP-bin to show that the main pathway for production of $\mathrm{CCN}$ from DMS is through nucleation of $\mathrm{H}_{2} \mathrm{SO}_{4}$ in the free troposphere, followed by coagulation and condensational growth. Korhonen et al. (2008) also found spatial differences in the CCN response when perturbing DMS flux. In a precursor to the study presented here, Woodhouse et al. (2010) investigated the impact on CCN number concentrations of using different sea-surface DMS climatologies in the modal aerosol scheme GLOMAP-mode. A global CCN sensitivity $\left(\Delta \mathrm{CCN} / \Delta\right.$ Flux $\left._{\text {DMS }}\right)$ of $63 \mathrm{~cm}^{-3}\left(\mathrm{mg} \mathrm{m}^{-2} \mathrm{day}^{-1} \text { sulphur }\right)^{-1}$ was found, with substantial regional variation $(-43$ to $\left.166 \mathrm{~cm}^{-3}\left(\mathrm{mg} \mathrm{m}^{-2} \mathrm{day}^{-1} \text { sulphur }\right)^{-1}\right)$. The wide range was attributed to differences in the spatial and temporal inhomogeneity of oceanic DMS, background CCN concentration, and differences in regional CCN production and removal efficiency. Woodhouse et al. (2010) concluded that, as a result of the low global mean CCN sensitivity and modest DMS flux changes predicted under global warming scenarios, the 
CLAW feedback is not important in modern-day climate change.

Despite the low CCN sensitivity on a global scale, some regions are sensitive to DMS flux changes (Woodhouse et al., 2010). The strong influence of wind speed on sea-air transfer, the observed changes in regional winds occurring over recent decades, and the potential geoengineering application of Wingenter et al. (2007), motivate this study. Here, the same microphysical aerosol scheme as used in Woodhouse et al. (2008) and Woodhouse et al. (2010) is used to explore the $\mathrm{CCN}$ sensitivity to regional sea-surface DMS perturbations and the processes that contribute to new CCN. Regions with high and low CCN sensitivities are highlighted and discussed in terms of the controls of CCN sensitivity.

\section{Methods}

\subsection{The aerosol model}

We use the modal version of the Global Model of Aerosol Processes, GLOMAP-mode (Manktelow et al., 2007; Mann et al., 2010) in the TOMCAT chemical transport model (Chipperfield, 2006). Meteorological fields in TOMCAT are from European Centre for Medium-Range Weather Forecasts (ECMWF) ERA-40 reanalyses (Uppala et al., 2005) for the year 2000 . The spatial resolution is $2.8^{\circ} \times 2.8^{\circ}$, with 31 vertical levels up to $10 \mathrm{hPa}$. GLOMAP represents seven gasphase sulphur species, with six-hourly monthly mean fields of $\mathrm{NO}_{3}, \mathrm{O}_{3}, \mathrm{OH}$ and $\mathrm{HO}_{2}$ driving DMS and $\mathrm{SO}_{2}$ oxidation (see Spracklen et al., 2005; Manktelow, 2008). GLOMAP contains internal mixtures of sulphate, sea-salt, black carbon (BC) and organic carbon (OC) (including secondary organics). The modal version of GLOMAP was recently shown to compare well with the more detailed sectional version (GLOMAP-bin) by Mann et al. (2012).

Anthropogenic and volcanic emissions are from AeroCom (Dentener et al., 2006), with size assumptions for primary emissions of BC, OC and sulphate as in Stier et al. (2005). Sea-salt emissions are calculated online in the model using the Gong (2003) parameterization between 0.035 and $30.0 \mu \mathrm{m}$ dry radius. Dust is neglected in this study, as the impact of dust on sulphate aerosol is small, even during a large dust storm (Lee et al., 2009; Manktelow et al., 2010). GLOMAP simulates aerosol microphysical processes such as coagulation, condensation, nucleation, cloud processing, and wet and dry deposition within a two-moment aerosol dynamics scheme. Aqueous-phase production of sulphate occurs through oxidation of $\mathrm{SO}_{2}$ with $\mathrm{O}_{3}$ and $\mathrm{H}_{2} \mathrm{O}_{2}$ in grid boxes containing low cloud according to the International Satellite Cloud Climatology Project monthly mean fields (Rossow and Schiffer, 1999). Only aerosol particles in the soluble modes with a dry radius greater than $37.5 \mathrm{~nm}$ are subject to growth from aqueous-phase oxidation.
Binary homogeneous nucleation of sulphuric acid particles is simulated based on Kulmala et al. (1998). Several studies (e.g. Spracklen et al., 2010) have shown that binary homogeneous nucleation cannot explain the boundary layer nucleation (BLN) events frequently seen in a range of environments (e.g. Kulmala et al., 2004). Yu et al. (2010) compared the effect of using different nucleation schemes in a global aerosol model on total aerosol number concentrations in the lower troposphere, and found that over remote oceans BLN is not required to explain observed number concentrations. Korhonen et al. (2008) and Yu and Luo (2009) found that nucleation in the free troposphere and subsequent re-entrainment in the boundary layer is the main source of sulphate particles over the tropical and mid-latitude oceans. Since Merikanto et al. (2009) showed that binary nucleation and primary emissions account for $\sim 90 \%$ of $\mathrm{CCN}$ in the marine boundary layer, we do not include a BLN parameterization here. GLOMAP-mode using Kulmala et al. (1998) has been verified against marine $\mathrm{CN}$ and $\mathrm{CCN}$ observations in Mann et al. $(2010,2012)$ and Woodhouse et al. (2010).

Sea-air DMS fluxes are calculated interactively based on the Kettle and Andreae (2000) observational sea-surface DMS climatology, with the Nightingale et al. (2000) wind speed dependent air-sea flux parameterization, giving an annual DMS flux of $18.6 \mathrm{Tg} \mathrm{a}^{-1}$ sulphur.

\subsection{Experiment setup}

To investigate further the global $\mathrm{CCN}$ sensitivity $\left(\Delta \mathrm{CCN} / \Delta\right.$ Flux $\left._{\mathrm{DMS}}\right)$ calculated in Woodhouse et al. (2010), multiple perturbations to sea-surface DMS concentration are applied to 20 patches located as shown in Fig. 2. The patch-perturbations are applied over approximately equal areas (2 million $\mathrm{km}^{2}$, to within $5 \%$ ) by increasing or decreasing sea-surface DMS concentrations in relation to the Kettle and Andreae (2000) climatology. When calculating $\mathrm{CCN}$ sensitivity, we define $\mathrm{CCN}$ as soluble particles larger than $35 \mathrm{~nm}$ dry radius, which corresponds to the minimum size particles would activate at $\sim 0.22 \%$ supersaturation.

Simulations are carried out with the sea-surface DMS concentration increased by $+0.5,+1.0,+2.0,+5.0$ and $+10.0 \mathrm{nM}$ for all patches, and decreases of $-0.5,-1.0$ and $-2.0 \mathrm{nM}$ to some patches, such that the concentration doesn't become negative. The magnitude of the patch perturbations is guided by the observed DMS responses to ocean iron addition experiments, as summarized in Boyd et al. (2007).

Results presented are monthly mean changes for December 1999 and June 2000, following a two month spin-up (with the patch perturbation applied). The definitions for absolute and relative DMS flux and CCN differences are as in Woodhouse et al. (2010), giving global mean differences for December and June: 


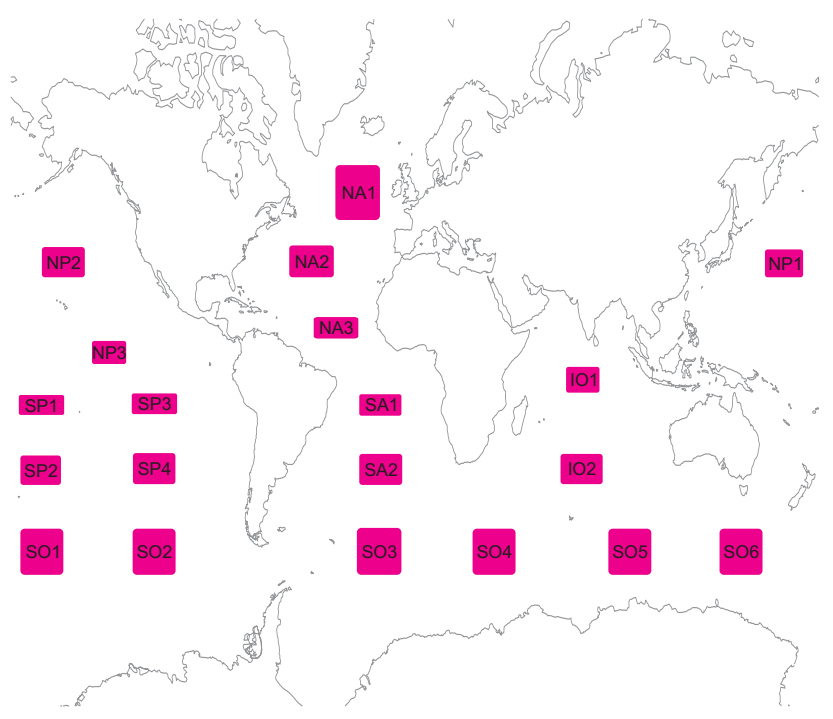

Fig. 2. The location, size and names of the 20 patches used in this study.

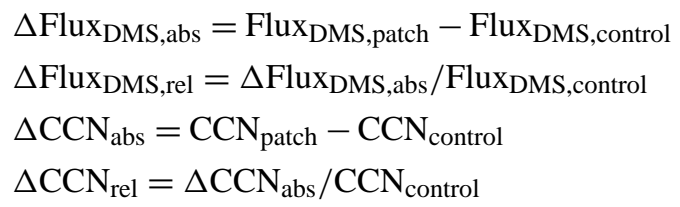

Note that $\triangle \mathrm{CCN}$ values are global surface means $\left(\mathrm{cm}^{-3}\right)$ and $\Delta$ Flux DMS values are global ocean-only means $\left(\mathrm{mg} \mathrm{m}^{-2} \mathrm{day}^{-1}\right.$ sulphur). In this study, there are multiple seasurface DMS perturbations for each patch, resulting in multiple datapoints on a plot of $\triangle$ Flux $_{\text {DMS }}$ vs. $\triangle \mathrm{CCN}$ (not shown). We fit a straight line to these data, deriving the $\mathrm{CCN}$ sensitivity as the gradient $(m)$ of the fit, and also calculate the Pearson correlation coefficient $(r)$. The majority of $r$ values are very close to 1 , suggesting a highly linear relationship between $\triangle \mathrm{CCN}$ and $\triangle$ Flux $_{\mathrm{DMS}}$ over the range of $\Delta$ Flux $_{\mathrm{DMS}}$ tested. Where the $r$ value is not close to 1 , the change in $\triangle \mathrm{CCN}$ is insignificant. We define the absolute $\mathrm{CCN}$ sensitivity as $\Delta \mathrm{CCN}_{\mathrm{abs}} / \Delta$ Flux $_{\mathrm{DMS} \text {,abs }}$ and the relative $\mathrm{CCN}$ sensitivity as $\Delta \mathrm{CCN}_{\mathrm{rel}} / \Delta \mathrm{Flux}_{\mathrm{DMS} \text {,rel. }}$ Thus, the relative $\mathrm{CCN}$ sensitivity is the fractional change in $\mathrm{CCN}$ per fractional change in DMS flux. For example, if a $10 \%$ change in DMS flux results in a $1 \%$ change in global mean $\mathrm{CCN}$ then relative $\mathrm{CCN}$ sensitivity is equal to 0.1 . Relative $\mathrm{CCN}$ sensitivity is the most useful metric because most model studies report the \% change in DMS flux, and the \% change in $\mathrm{CCN}$ takes into account the background CCN (from other sources) and is most relevant to cloud albedo.

\section{Results and discussion}

\subsection{Absolute CCN sensitivities}

The December mean surface $\mathrm{CCN}$ concentration for the control simulation is shown in Fig. 3a. Figure $3 \mathrm{~b}$ is an example of the surface $\mathrm{CCN}$ response to a $+2.0 \mathrm{nM}$ perturbation to the South Pacific patch SP2. The peak CCN response from the patch is $\sim 2 \mathrm{~cm}^{-3}$, and occurs some distance from the patch as additionally nucleated particles are transported while growing to $\mathrm{CCN}$ sizes. Another peak in $\triangle \mathrm{CCN}$ occurs over the patch and is caused by growth of Aitken mode particles to CCN size. This "double-peak" behaviour was noted in Woodhouse et al. (2008). The global mean CCN response is $0.08 \mathrm{~cm}^{-3}$. The areas of decreased $\mathrm{CCN}$ concentration in Fig. 3 suggest that the $\mathrm{CCN}$ response is complex.

The absolute sensitivity of $\mathrm{CCN}(>35 \mathrm{~nm}$ dry radius) to DMS flux perturbations in all 20 patches is shown in the top panels in Fig. 4. There is a large range of sensitivities, varying with month and location, from $12 \mathrm{~cm}^{-3}\left(\mathrm{mg} \mathrm{m}^{-2} \mathrm{day}^{-1} \text { sulphur) }\right)^{-1} \quad$ (patch SA1) to $261 \mathrm{~cm}^{-3}\left(\mathrm{mg} \mathrm{m}^{-2} \mathrm{day}^{-1}\right.$ sulphur) ${ }^{-1} \quad$ (SP1), both in December in the Southern Hemisphere (SH). Hemispheric and global mean $\mathrm{CCN}$ sensitivities are summarized in Table 1. The June and December combined hemispheric mean $\mathrm{CCN}$ sensitivity is $80 \mathrm{~cm}^{-3}\left(\mathrm{mg} \mathrm{m}^{-2} \text { day }^{-1} \text { sulphur }\right)^{-1}$, slightly higher but comparable to the $63 \mathrm{~cm}^{-3}\left(\mathrm{mg} \mathrm{m}^{-2} \text { day }^{-1} \text { sulphur }\right)^{-1}$ mean calculated in Woodhouse et al. (2010).

The mean summer hemisphere $\mathrm{CCN}$ sensitivity is $75 \mathrm{~cm}^{-3}\left(\mathrm{mg} \mathrm{m}^{-2} \mathrm{day}^{-1} \text { sulphur }\right)^{-1}$, compared to the winter hemisphere value of $82 \mathrm{~cm}^{-3}\left(\mathrm{mg} \mathrm{m}^{-2} \mathrm{day}^{-1} \text { sulphur }\right)^{-1}$. These sensitivities are higher than the equivalents in Woodhouse et al. (2010), 47 and $78 \mathrm{~cm}^{-3}\left(\mathrm{mg} \mathrm{m}^{-2} \mathrm{day}^{-1} \text { sulphur }\right)^{-1}$ for summer and winter hemispheres respectively, but repeat the pattern of the winter hemisphere CCN being more sensitive to changes in DMS flux than the summer hemisphere. The contrast in CCN sensitivities between summer and winter hemispheres is less here than in Woodhouse et al. (2010). In the present study, the location of the patches determines the mean sensitivity, so it is difficult to compare with Woodhouse et al. (2010) where are an inhomogeneous global distribution of DMS was perturbed.

\subsection{Relative CCN sensitivities}

Relative CCN sensitivities are summarized in the lower panels of Fig. 4. A high background CCN concentration (compared to a low background $\mathrm{CCN}$ concentration) leads to a lower relative $\mathrm{CCN}$ sensitivity for a given increase in $\mathrm{CCN}$. Relative CCN sensitivities are calculated as in Woodhouse et al. (2010), by adding sub-micron sea-salt CCN contributions from a simulation in GLOMAP-bin. 

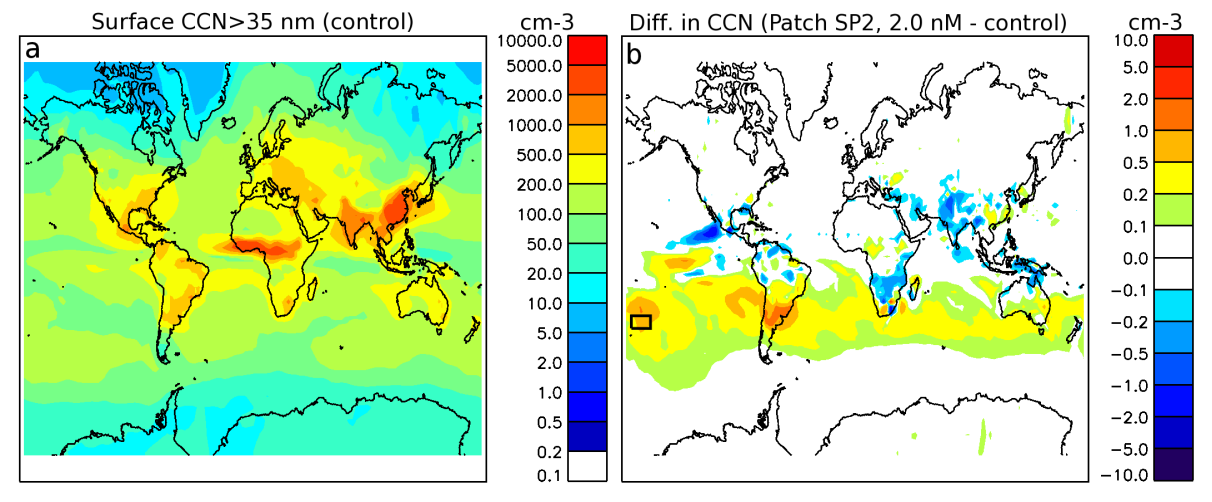

Fig. 3. (a) December mean surface $\mathrm{CCN}>35 \mathrm{~nm}$ concentration for the control simulation and (b) difference in surface $\mathrm{CCN}>35 \mathrm{~nm}$ concentration resulting from the SP2 patch (location indicated by black box) with $+2.0 \mathrm{nM}$ DMS perturbation.
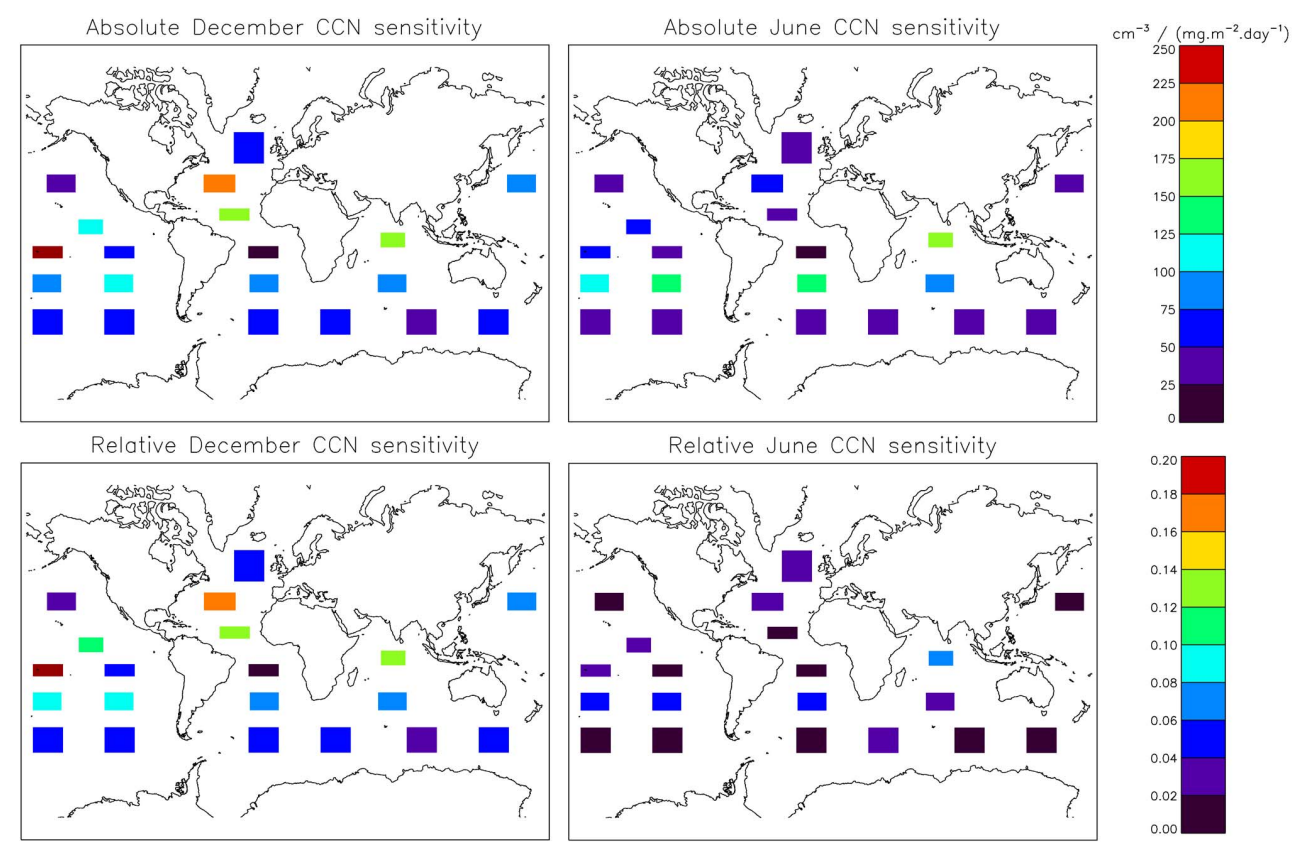

Fig. 4. Global mean absolute (top panels) and relative (bottom panels) CCN sensitivities for each patch for December (left) and June (right). The position of the shaded patches on the maps corresponds to the location of the perturbed patch in the experiment. The colour of the patch indicates the global mean sensitivity arising from that patch.

Relative sensitivities lie between $<0.01$ and 0.22 . The efficiency with which DMS adds to global CCN therefore varies by a factor of $>20$, with a strong spatial dependence on where the DMS is emitted. Relative CCN sensitivity means are summarized in Table 1 . The combined hemispheric June and December mean CCN sensitivity is 0.06 , close to the equivalent sensitivity (0.05) calculated in Woodhouse et al. (2010) from present-day climatologies. Mean relative summer hemisphere $\mathrm{CCN}$ sensitivity here is 0.06 , slightly higher than the winter hemisphere sensitivity of 0.05 .

\subsection{Microphysical pathways to new $\mathrm{CCN}$}

We examine the response of chemical and aerosol processes to the patch perturbations in order to explore the reasons behind the spatially variable $\mathrm{CCN}$ sensitivities noted in the previous section. The processes considered here are oxidation from DMS to $\mathrm{SO}_{2}$, gas-phase oxidation from $\mathrm{SO}_{2}$ to $\mathrm{H}_{2} \mathrm{SO}_{4}$, $\mathrm{H}_{2} \mathrm{SO}_{4}$ nucleating to form new particles, growth of existing particles (condensation of $\mathrm{H}_{2} \mathrm{SO}_{4}$ vapour onto the nucleation and Aitken modes), aqueous-phase (in-cloud) oxidation of $\mathrm{SO}_{2}$ to aerosol sulphate, and aerosol deposition (total dry deposition, impact and nucleation scavenging of sulphate from all modes). These processes are shown schematically 
Table 1. Summary of absolute (units $\mathrm{cm}^{-3}\left(\mathrm{mg} \mathrm{m}^{-2}\right.$ day $^{-1}$ sulphur) ${ }^{-1}$ ) and relative CCN sensitivities resulting from the DMS flux perturbations.

\begin{tabular}{lcc|cc}
\hline & \multicolumn{2}{c|}{ Absolute } & \multicolumn{2}{c}{ Relative } \\
\cline { 2 - 5 } & Dec & Jun & Dec & Jun \\
\hline Global & 94 & 63 & 0.08 & 0.03 \\
NH & 115 & 50 & 0.09 & 0.02 \\
SH & 85 & 68 & 0.07 & 0.03 \\
\hline
\end{tabular}

in Fig. 5, and can be divided into "production" (those that form new $\mathrm{CCN}$ ) and "removal" (those that remove $\mathrm{CCN}$ ) processes. The aqueous-phase oxidation process is classified separately from the production and removal processes, as aqueous-phase oxidation does not lead to the formation of new $\mathrm{CCN}$, but rather adds mass to existing $\mathrm{CCN}$. In contrast to the CCN sensitivities, which are surface level means, the process sensitivities are whole-atmosphere means. Considering whole-atmosphere means is necessary because processes which lead to enhanced $\mathrm{CCN}$ near the surface may have occurred at different levels in the atmosphere, e.g. nucleation in the model mostly occurs in the free troposphere.

The processes are defined in terms of mass fluxes of sulphur:

$\Delta$ Flux $_{\text {process }, \mathrm{abs}}=$ Flux $_{\text {process,patch }}-$ Flux $_{\text {process,control }}$

where "process" is one of the processes shown in Fig. 5. As with the CCN sensitivities, the process sensitivities are calculated by fitting a straight line to the datapoints on a plot of $\Delta$ Flux $_{\text {DMS }}$ vs. $\Delta$ Flux $_{\text {process,abs }}$ (not shown). The majority of the calculated correlation coefficients $r$ for these fitted lines are very close to 1 (not shown).

\subsection{Microphysical control of CCN sensitivity}

As already noted, the two patches with the highest and lowest absolute CCN sensitivities are SP1 in the South Pacific and SA1 in the South Atlantic. Both patches are located at the same latitude (centred on $14^{\circ} \mathrm{S}$ ), and are located near the centre (longitudinally) of their respective oceans. Despite these similarities, they have very different process sensitivities leading to very different $\mathrm{CCN}$ responses.

Like CCN sensitivity, the process sensitivities depend on month and patch location. Figure 6 shows the absolute process sensitivities. Relative sensitivities are not discussed, as they are strongly influenced by the background rates of each process. Note the different orders of magnitude involved in the absolute process sensitivities. The magnitude of the sensitivity does not indicate its importance for $\mathrm{CCN}$ in comparison with the other sensitivities.

To compare the sensitivities we use the standard score $Z$ :

$Z=(X-\mu) / \sigma$

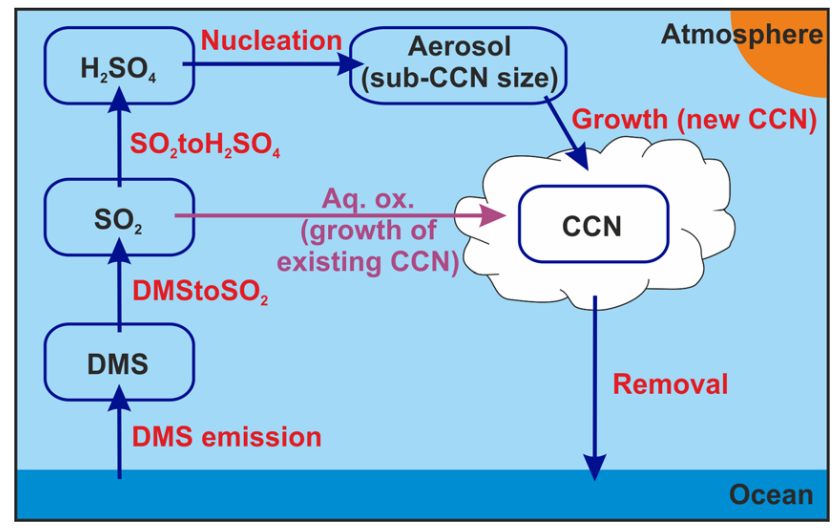

Fig. 5. Schematic indicating the processes through which DMSderived sulphur can form new $\mathrm{CCN}$. The aqueous-phase oxidation process is also included (highlighted in purple), despite not forming new $\mathrm{CCN}$.

where $X$ is the value to be standardized, $\mu$ is the combined June and December mean, and $\sigma$ is the combined June and December standard deviation of the process in question. The standard score shows the relationship of the variable to the mean in terms of standard deviations, so that a standard score of one is $1 \sigma$ above the mean. To understand which processes control CCN sensitivity we plot the CCN sensitivity against the process standard score (Figs. 7 and 8).

The data in Figs. 7 and 8 do not show which process is responsible for a high or low $\mathrm{CCN}$ sensitivity in any one patch, but it does give an indication as to the global importance of a process in influencing $\mathrm{CCN}$ sensitivity. There is no statistically significant correlation between CCN sensitivity standard score and the DMS to $\mathrm{SO}_{2}$ sensitivity standard score at the $95 \%$ confidence level in either December or June. In December, the $\mathrm{SO}_{2}$ to $\mathrm{H}_{2} \mathrm{SO}_{4}$ sensitivity standard score shows good correlation with the $\mathrm{CCN}$ sensitivity standard score, with an $r$ value of 0.71 (statistically significant at $99.95 \%$ confidence level). The correlation is much lower in June, $r=0.36$, though visually the correlation appears to be reasonable. There is no correlation between CCN sensitivity standard score and nucleation sensitivity standard score in December, but a statistically significant correlation $(r=0.63)$ at $99.5 \%$ confidence level in June. The correlation in June is not necessarily robust however, as many of the datapoints are clustered near zero, and only a few have higher sensitivities relative to the global mean. December CCN sensitivity standard score vs. growth sensitivity standard score has an $r$ value of 0.78 (significant at $99.95 \%$ confidence level). June CCN sensitivity standard score vs. growth sensitivity standard score is slightly lower $(r=0.66$, statistically significant at $99.5 \%$ confidence level), but also suffers from having few datapoints at higher values. The deposition sensitivity standard scores have an inverse relationship to CCN sensitivity standard scores, with $r=-0.56$ in December ( $99.5 \%$ significance) and $r=-0.41$ (95\% significance). 


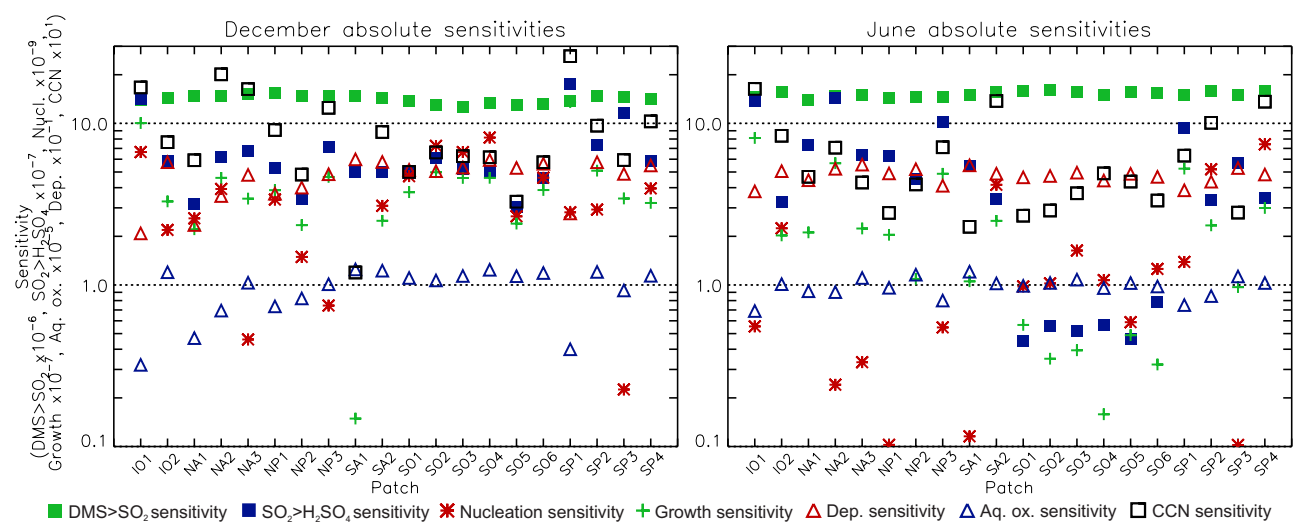

Fig. 6. Absolute sensitivities of processes and CCN. Absolute sensitivities for the different processes cover several orders of magnitude, and are accounted for by multiplying the value from the plot by the scaling indicated on the y-axis. Units for $\Delta \mathrm{CCN}_{\mathrm{abs}} / \Delta$ Flux $_{\mathrm{DMS} \text {,abs }}$ are $\mathrm{cm}^{-3}\left(\mathrm{mg} \mathrm{m}^{-2} \mathrm{day}^{-1} \text { sulphur }\right)^{-1} ; \quad \Delta$ Flux $_{\mathrm{DMS}_{\text {to }} \mathrm{SO}_{2} \text {, abs }} / \Delta \mathrm{Flux}_{\mathrm{DMS} \text {,abs }}$, $\Delta$ Flux $_{\mathrm{SO}_{2}}$ to $\mathrm{H}_{2} \mathrm{SO}_{4}$,abs $/ \Delta$ Flux $_{\mathrm{DMS}, \text { abs }}, \Delta$ Flux $_{\text {Nucl.,abs }} / \Delta$ Flux $_{\text {DMS,abs }}, \Delta$ Flux $_{\text {Aq.ox.,abs }} / \Delta$ Flux $_{\text {DMS, abs }}$ and $\Delta$ Flux $_{\text {Growth,abs }} / \Delta$ Flux $_{\text {DMS, abs }}$

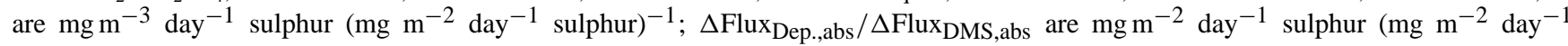
sulphur $)^{-1}$.
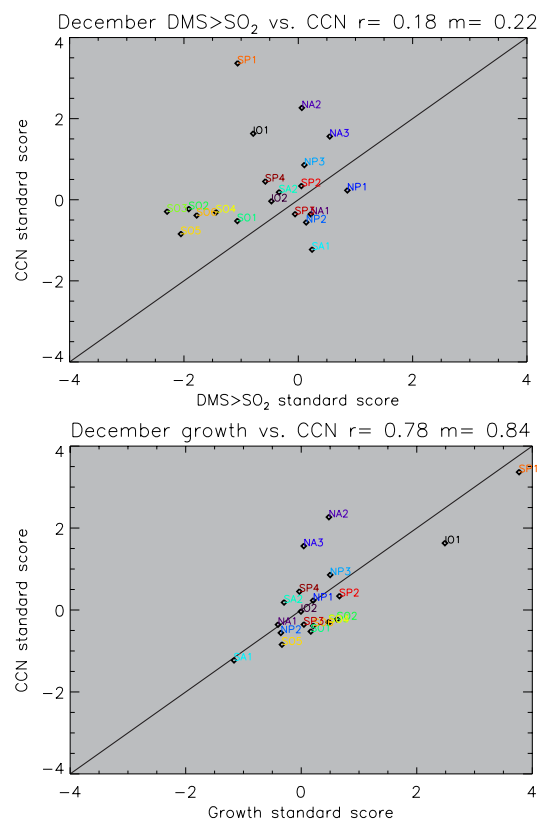
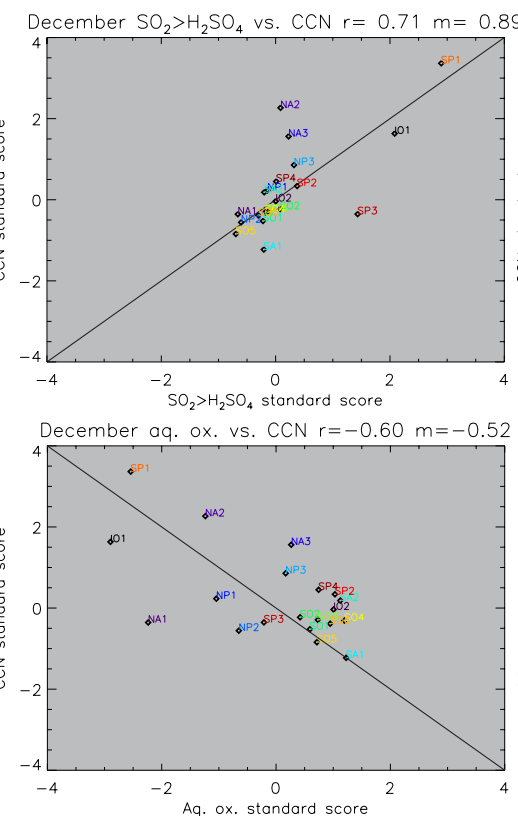
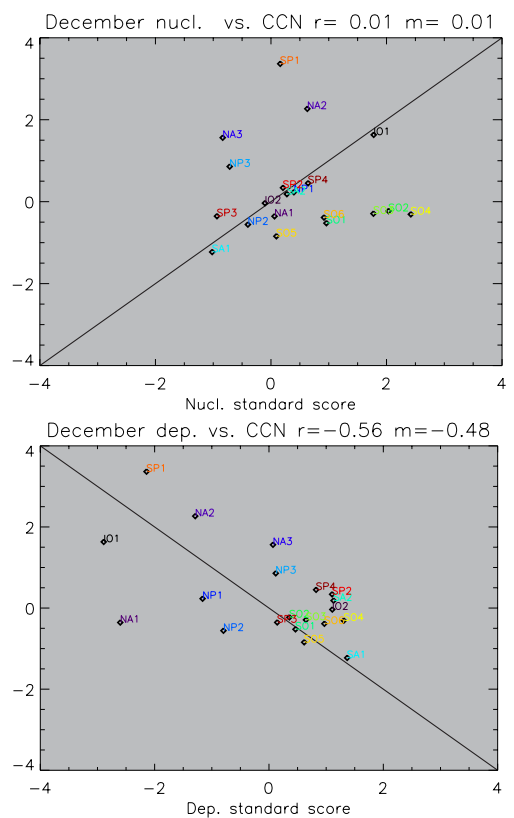

Fig. 7. December standard scores for $\mathrm{CCN}$ sensitivities plotted against the process sensitivities for each patch. Also shown are the $1: 1$ line (or negative $1: 1$ line), $r$ and $m$ values of the linear best fit. The patch names are shown next to their respective datapoints. Colours are used to help differentiate the datapoints from one another.

Standard scores for $\mathrm{CCN}$ sensitivity are correlated against the aqueous-phase oxidation sensitivity in Figs. 7 and 8. The December Pearson correlation coefficient $r$ in Fig. 7 is -0.60 , significant at the $99 \%$ confidence level. In June the correlation is -0.50 , significant at the $95 \%$ confidence level. These negative correlations confirm that a high aqueous-phase oxidation rate near the patch restricts $\mathrm{CCN}$ production from DMS-derived $\mathrm{SO}_{2}$, leading to a low sensitivity.
The production processes track the stages through which DMS-derived sulphur goes to form new CCN. The correlations in Figs. 7 and 8 show a close link between CCN sensitivity and the $\mathrm{SO}_{2}$ to $\mathrm{H}_{2} \mathrm{SO}_{4}$, growth, and aqueous-phase oxidation processes. The DMS to $\mathrm{SO}_{2}$ oxidation process has little influence on $\mathrm{CCN}$ sensitivity. The $\mathrm{SO}_{2}$ to $\mathrm{H}_{2} \mathrm{SO}_{4}$, growth, and aqueous-phase oxidation processes are closely linked. The fate of $\mathrm{SO}_{2}$ is significant, as in order to form new $\mathrm{CCN}$, $\mathrm{SO}_{2}$ must be oxidized in the gas-phase to $\mathrm{H}_{2} \mathrm{SO}_{4}$ that can 

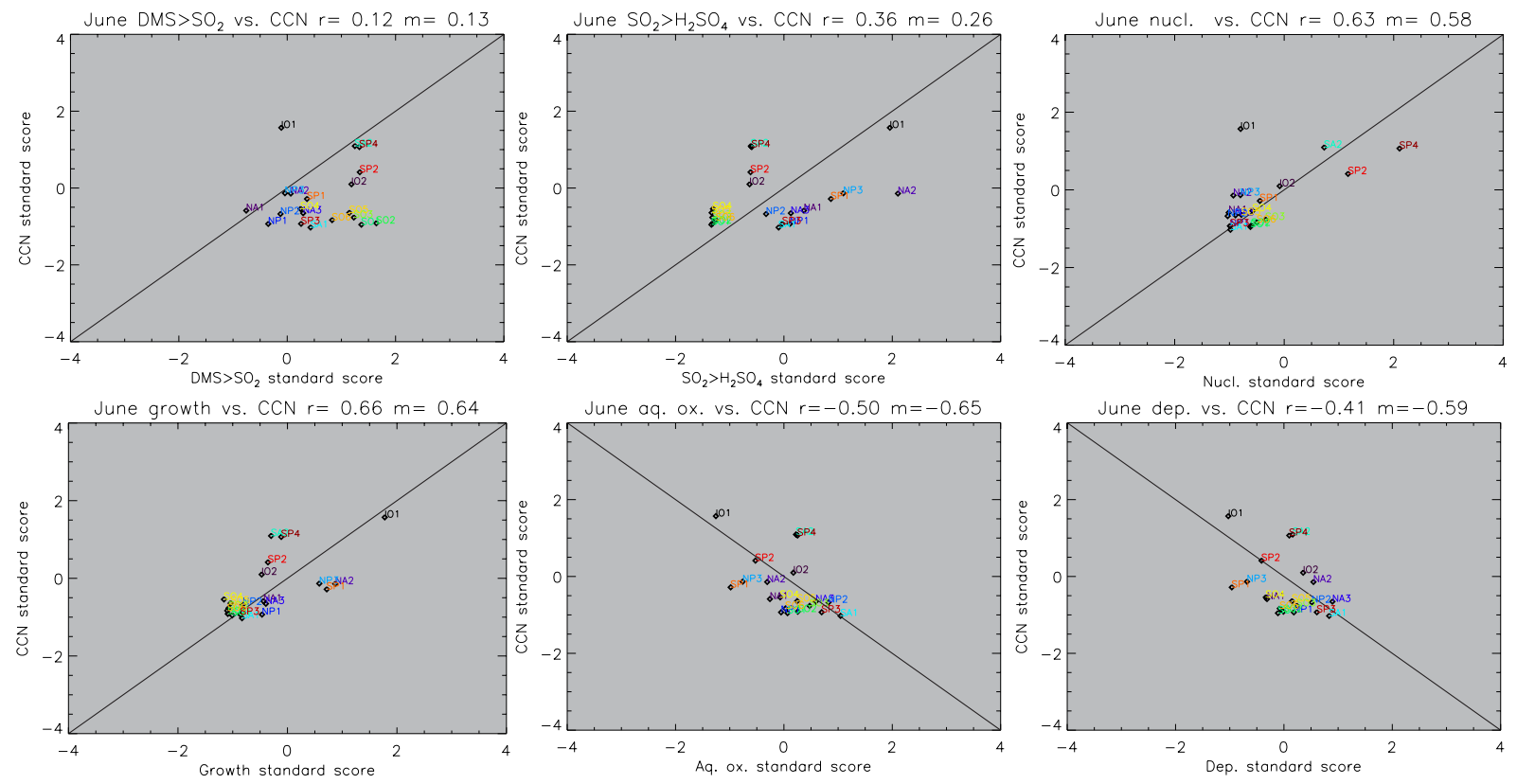

Fig. 8. June standard scores for CCN sensitivities plotted against the process sensitivities for each patch. Also shown are the $1: 1$ line (or negative $1: 1$ line), $r$ and $m$ values of the linear best fit. The patch names are shown next to their respective datapoints. Colours are used to help differentiate the datapoints from one another.

subsequently nucleate new particles or condense onto existing particles, growing them to CCN sizes. Andreae et al. (1999), O'Dowd et al. (1999b) and Yang et al. (2011) have demonstrated from observations that aqueous-phase oxidation of $\mathrm{SO}_{2}$ is the dominant pathway for sulphate production in regions of marine stratocumulus clouds. Despite not yielding new $\mathrm{CCN}$, aqueous-phase oxidation can influence $\mathrm{CCN}$ formation indirectly by diverting $\mathrm{SO}_{2}$ away from gas-phase $\mathrm{H}_{2} \mathrm{SO}_{4}$ and therefore suppressing condensational growth.

The link between CCN sensitivity and aqueous-phase oxidation is clear in the patches with the two highest $\mathrm{CCN}$ sensitivities (SP1 and NA2 in December). In both of these patches, the aqueous-phase oxidation sensitivity is low, and so does not limit formation of new CCN. Also of interest is patch NA3, situated in the biomass burning outflow from North Africa. Patch NA3 has a high CCN sensitivity, but an aqueous-phase oxidation sensitivity near the mean. It is likely that the high CCN sensitivity of NA3 is the result of the biomass burning aerosol providing an abundant source of Aitken mode particles that are aged and grown to $\mathrm{CCN}$ relevant size.

The effect of aqueous-phase oxidation on $\mathrm{CCN}$ sensitivity also explains the uniformity of DMS to $\mathrm{SO}_{2}$ sensitivity between different patches compared to the $\mathrm{SO}_{2}$ to $\mathrm{H}_{2} \mathrm{SO}_{4}$ sensitivity, which varies over an order of magnitude (Fig. 6). Thus, the competition for $\mathrm{SO}_{2}$ from aqueous-phase oxidation introduces significant variability into the $\mathrm{SO}_{2}$ to $\mathrm{H}_{2} \mathrm{SO}_{4}$ sensitivities.

\section{Conclusions}

A global microphysical aerosol model was used to investigate the $\mathrm{CCN}$ response resulting from 20 patch perturbations to sea-surface DMS concentration. The study revealed seasonally and spatially variable $C C N$ sensitivities $\left(\Delta C C N / \Delta\right.$ Flux $\left._{\text {DMS }}\right)$, from 12 to $261 \mathrm{~cm}^{-3}\left(\mathrm{mg} \mathrm{m}^{-2} \mathrm{day}^{-1} \text { sulphur }\right)^{-1}$. Relative CCN sensitivities range from $<0.01$ to 0.22 . A patch in the tropical South Pacific Ocean in December has the highest absolute and relative $\mathrm{CCN}$ responses to changes in the DMS flux. The mean $\mathrm{CCN}$ sensitivities are comparable to those calculated in Woodhouse et al. (2010), suggesting that the sensitivities are robust after being calculated using two different approaches. The generally low CCN sensitivities calculated in this study and in Woodhouse et al. (2010) suggest that future changes in DMS flux as a result of small-scale changes in phytoplankton activity will not be important for present-day climate change.

There are two implications of our model results for the role of DMS in climate regulation.

1. The spatial distribution of DMS emission changes is likely to be more important for climate regulation than absolute global mean changes in flux because CCN sensitivity varies by a factor of 20 between regions. Changes in the distribution of DMS emissions could be caused by changes in wind speed or changes in phytoplankton distribution. The local changes in wind speeds over recent decades highlighted in Sect. 1 could have 
significant local implications for DMS flux, due to the strong dependence of DMS flux on wind speed. The coincidence of these wind speed changes with regions of high CCN sensitivity could therefore be important for CCN concentrations locally. For example, wind speed increases in the tropical North Atlantic and decreases in the sub-tropical North Pacific are coincident with moderate to high CCN sensitivities (in December), while the wind speed changes identified in Korhonen et al. (2010) in the Southern Ocean are coincident with low $\mathrm{CCN}$ sensitivities. If a changing climate leads to adjustments in the location of DMS-producers (e.g. CameronSmith et al., 2011), the spatially variable CCN sensitivities may cause changes in the production of $\mathrm{CCN}$ even for a constant global DMS flux. Cameron-Smith et al. (2011) calculate an increase in DMS flux between 60 and $70^{\circ} \mathrm{S}$ of $70 \%$ resulting from an increased $\mathrm{CO}_{2}$ scenario within a coupled climate model with a marine biogeochemical module. However, we have shown here that the Southern Ocean is a region of low CCN sensitivity. For the Southern Ocean patches (SO1-6 at 50 to $60^{\circ} \mathrm{S}$ ) the relative CCN sensitivity is 0.03 . Thus a $70 \%$ increase in DMS flux would cause only a $2.1 \%$ increase in CCN. Loss of Arctic sea-ice could also lead to a new source of CCN from DMS (and also sea-salt), potentially offsetting the decrease in surface albedo with an increase in cloud albedo. A fully-coupled earth system model, with a comprehensive representation of aerosol and cloud microphysics and detailed marine ecosystem model, is required to study these links further.

2. The sensitivity of CCN to changes in DMS emission is suppressed in regions of low cloud because the DMSderived $\mathrm{SO}_{2}$ tends to be oxidized in cloud droplets rather than in the gas-phase, resulting in growth of existing $\mathrm{CCN}$ rather than production of new $\mathrm{CCN}$. To be effective in climate regulation, $\mathrm{CCN}$ changes in cloudy regions are required, thus the suppression of $\mathrm{CCN}$ formation in cloudy regions limits the CLAW mechanism. This model-derived result matches the fate of sulphur species in marine stratocumulus clouds observed in field observations Andreae et al. (1999), O’Dowd et al. (1999b) and Yang et al. (2011) and predicted in models (e.g. O'Dowd et al., 1999a). To form new CCN from DMS, $\mathrm{SO}_{2}$ must be oxidized in the gas-phase to form $\mathrm{H}_{2} \mathrm{SO}_{4}$ which is available for nucleation of new particles and condensational growth. The representation of aqueous-phase oxidation (and by association, clouds) in microphysical aerosol models will strongly influence the CCN response to DMS flux perturbations.

While the focus of this study has been on CCN response to perturbations to natural DMS emissions, the findings are equally applicable to surface emissions of $\mathrm{SO}_{2}$, e.g. from anthropogenic sources. For example, variations in the oxidation pathways of $\mathrm{SO}_{2}$ also influence differences in the production of $\mathrm{CCN}$ from anthropogenic $\mathrm{SO}_{2}$ from different continents (Manktelow et al., 2009). The results are particularly important for $\mathrm{CCN}$ production from shipping emissions. Although changes in cloud properties are clearly associated with ship tracks (Taylor et al., 2000), the perturbations in cloud droplet concentrations will be strongly controlled by the fraction of $\mathrm{SO}_{2}$ that is oxidized in the cloud droplets compared to the fraction that forms gas-phase sulphuric acid. The higher production efficiency of $\mathrm{CCN}$ from emissions in cloud-free regions suggests that far-field effects of ship-emitted $\mathrm{SO}_{2}$ should be considered. $\mathrm{CCN}$ sensitivity from $\mathrm{SO}_{2}$ emitted from volcanoes is likely to be higher than that from other $\mathrm{SO}_{2}$ sources, as continuously degassing volcanoes usually emit directly into the free troposphere, where aqueous-phase oxidation is less important (Schmidt et al., 2012).

Acknowledgements. MTW was funded by a NERC UKSOLAS CASE studentship with the UK Met Office, and thanks Steven J. Pickering for his help with GLOMAP, Joonas Merikanto for sub-micron sea-salt CCN contributions, and Tom Breider, Lindsay Lee and Anja Schmidt for discussion. The work of OB was supported by the Joint DECC and Defra Integrated Climate Programme - DECC/Defra (GA01101). GWM is an NCAS funded Research Fellow.

Edited by: F. Yu

\section{References}

Albrecht, B. A.: Aerosols, cloud microphysics, and fractional cloudiness, Science, 245, 1227-1230, 1989.

Andreae, M. O., Elbert, W., Cai, Y., Andreae, T. W., and Gras, J.: Non-sea-salt sulfate, methanesulfonate, and nitrate aerosol concentrations and size distributions at Cape Grim, Tasmania RID B1068-2008, J. Geophys. Res.-Atmos., 104, 21695-21706, 1999.

Ayers, G. P. and Cainey, J. M.: The CLAW hypothesis: a review of the major developments, Environ. Chem., 4, 366-374, 2007.

Barnes, I., Hjorth, J., and Mihalopoulos, N.: Dimethyl sulfide and dimethyl sulfoxide and their oxidation in the atmosphere, Chem. Rev., 106, 940-975, 2006.

Bopp, L., Boucher, O., Aumont, O., Belviso, S., Dufresne, J. L., Pham, M., and Monfray, P.: Will marine dimethylsulfide emissions amplify or alleviate global warming? A model study, Can. J. Fish. Aquat. Sci., 61, 826-835, 2004.

Boyd, P. W., Jickells, T., Law, C. S., Blain, S., Boyle, E. A., Buesseler, K. O., Coale, K. H., Cullen, J. J., de Baar, H. J. W., Follows, M., Harvey, M., Lancelot, C., Levasseur, M., Owens, N. P. J., Pollard, R., Rivkin, R. B., Sarmiento, J., Schoemann, V., Smetacek, V., Takeda, S., Tsuda, A., Turner, S., and Watson, A. J.: Mesoscale iron enrichment experiments 19932005: Synthesis and future directions, Science, 315, 612-617, 2007.

Cameron-Smith, P., Elliott, S., Maltrud, M., Erickson, D., and Wingenter, O.: Changes in dimethyl sulfide oceanic distribution due to climate change, Geophys. Res. Lett., 38, L07704, doi:10.1029/2011GL047069, 2011. 
Carslaw, K. S., Boucher, O., Spracklen, D. V., Mann, G. W., Rae, J. G. L., Woodward, S., and Kulmala, M.: A review of natural aerosol interactions and feedbacks within the Earth system, Atmos. Chem. Phys., 10, 1701-1737, doi:10.5194/acp-10-17012010, 2010.

Charlson, R. J., Lovelock, J. E., Andreae, M. O., and Warren, S. G.: Oceanic phytoplankton, atmospheric sulfur, cloud albedo and climate, Nature, 326, 655-661, 1987.

Chin, M. A. and Jacob, D. J.: Anthropogenic and natural contributions to tropospheric sulfate: a global model analysis, J. Geophys. Res.-Atmos., 101, 18691-18699, 1996.

Chipperfield, M. P.: New version of the TOMCAT/SLIMCAT offline chemical transport model: intercomparison of stratospheric tracer experiments, Q. J. Roy. Meteorol. Soc., 132, 1179-1203, 2006.

Dentener, F., Kinne, S., Bond, T., Boucher, O., Cofala, J., Generoso, S., Ginoux, P., Gong, S., Hoelzemann, J. J., Ito, A., Marelli, L., Penner, J. E., Putaud, J.-P., Textor, C., Schulz, M., van der Werf, G. R., and Wilson, J.: Emissions of primary aerosol and precursor gases in the years 2000 and 1750 prescribed data-sets for AeroCom, Atmos. Chem. Phys., 6, 43214344, doi:10.5194/acp-6-4321-2006, 2006.

Gabric, A. J., Whetton, P. H., and Cropp, R.: Dimethylsulphide production in the subantarctic southern ocean under enhanced greenhouse conditions, Tellus B, 53, 273-287, 2001.

Gong, S. L.: A parameterization of sea-salt aerosol source function for sub- and super-micron particles, Global Biogeochem. Cy., 17, 1097, doi:10.1029/2003GB002079, 2003.

Gunson, J. R., Spall, S. A., Anderson, T. R., Jones, A., Totterdell, I. J., and Woodage, M. J.: Climate sensitivity to ocean dimethylsulphide emissions, Geophys. Res. Lett., 33, L07701, doi:10.1029/2005GL024982, 2006.

Kettle, A. J. and Andreae, M. O.: Flux of dimethylsulfide from the oceans: a comparison of updated data seas and flux models, J. Geophys. Res.-Atmos., 105, 26793-26808, 2000.

Korhonen, H., Carslaw, K. S., Spracklen, D. V., Mann, G. W., and Woodhouse, M. T.: Influence of oceanic dimethyl sulfide emissions on cloud condensation nuclei concentrations and seasonality over the remote Southern Hemisphere oceans: a global model study, J. Geophys. Res.-Atmos., 113, D15204, doi:10.1029/2007JD009718, 2008.

Korhonen, H., Carslaw, K. S., Forster, P. M., Mikkonen, S., Gordon, N. D., and Kokkola, H.: Aerosol climate feedback due to decadal increases in Southern Hemisphere wind speeds, Geophys. Res. Lett., 37, L02805, doi:10.1029/2009GL041320, 2010.

Kulmala, M., Laaksonen, A., and Pirjola, L.: Parameterizations for sulfuric acid/water nucleation rates, J. Geophys. Res.-Atmos., 103, 8301-8307, 1998.

Kulmala, M., Vehkamaki, H., Petaja, T., Dal Maso, M., Lauri, A., Kerminen, V. M., Birmili, W., and McMurry, P. H.: Formation and growth rates of ultrafine atmospheric particles: a review of observations, J. Aerosol Sci., 35, 143-176, 2004.

Lee, Y. H., Chen, K., and Adams, P. J.: Development of a global model of mineral dust aerosol microphysics, Atmos. Chem. Phys., 9, 2441-2458, doi:10.5194/acp-9-2441-2009, 2009.

Liss, P. S., Hatton, A. D., Malin, G., Nightingale, P. D., and Turner, S. M.: Marine sulphur emissions, Philos. T. Roy. Soc. B, 352, 159-168, 1997.
Manktelow, P. T.: Understanding the Complex Behaviour of Tropospheric Sulfate in a Global Aerosol Microphysics Model, Ph. D. thesis, School of Earth and Environment, University of Leeds, Leeds, UK, 2008.

Manktelow, P. T., Mann, G. W., Carslaw, K. S., Spracklen, D. V., and Chipperfield, M. P.: Regional and global trends in sulfate aerosol since the 1980s, Geophys. Res. Lett., 34, L14803, doi:10.1029/2006GL028668, 2007.

Manktelow, P. T., Carslaw, K. S., Mann, G. W., and Spracklen, D. V.: Variable CCN formation potential of regional sulfur emissions, Atmos. Chem. Phys., 9, 3253-3259, doi:10.5194/acp-9-3253-2009, 2009.

Manktelow, P. T., Carslaw, K. S., Mann, G. W., and Spracklen, D. V.: The impact of dust on sulfate aerosol, $\mathrm{CN}$ and $\mathrm{CCN}$ during an East Asian dust storm, Atmos. Chem. Phys., 10, 365-382, doi:10.5194/acp-10-365-2010, 2010.

Mann, G. W., Carslaw, K. S., Spracklen, D. V., Ridley, D. A., Manktelow, P. T., Chipperfield, M. P., Pickering, S. J., and Johnson, C. E.: Description and evaluation of GLOMAP-mode: a modal global aerosol microphysics model for the UKCA composition-climate model, Geosci. Model Dev., 3, 519-551, doi:10.5194/gmd-3-519-2010, 2010.

Mann, G. W., Carslaw, K. S., Ridley, D. A., Spracklen, D. V., Pringle, K. J., Merikanto, J., Korhonen, H., Schwarz, J. P., Lee, L. A., Manktelow, P. T., Woodhouse, M. T., Schmidt, A., Breider, T. J., Emmerson, K. M., Reddington, C. L., Chipperfield, M. P., and Pickering, S. J.: Intercomparison of modal and sectional aerosol microphysics representations within the same 3-D global chemical transport model, Atmos. Chem. Phys., 12, 4449-4476, doi:10.5194/acp-12-4449-2012, 2012.

Mellor, G. L. and Durbin, P. A.: Structure and dynamics of ocean surface mixed layer, J. Phys. Oceanogr., 5, 718-728, 1975.

Merikanto, J., Spracklen, D. V., Mann, G. W., Pickering, S. J., and Carslaw, K. S.: Impact of nucleation on global CCN, Atmos. Chem. Phys., 9, 8601-8616, doi:10.5194/acp-9-8601-2009, 2009.

Nightingale, P. D., Malin, G., Law, C. S., Watson, A. J., Liss, P. S., Liddicoat, M. I., Boutin, J., and Upstill-Goddard, R. C.: In situ evaluation of air-sea gas exchange parameterizations using novel conservative and volatile tracers, Global Biogeochem. Cy., 14, 373-387, 2000.

O’Dowd, C. D., Lowe, J. A., and Smith, M. H.: Coupling sea-salt and sulphate interactions and its impact on cloud droplet concentration predictions, Geophys. Res. Lett., 26, 1311-1314, 1999a.

O'Dowd, C. D., Lowe, J. A., and Smith, M. H.: Observations and modelling of aerosol growth in marine stratocumulus - case study, Atmos. Environ., 33, 3053-3062, 1999b.

Quinn, P. K. and Bates, T. S.: The case against climate regulation via oceanic phytoplankton sulphur emissions, Nature, 480, 5156, 2011.

Rossow, W. B. and Schiffer, R. A.: Advances in understanding clouds from ISCCP, B. Am. Meteorol. Soc., 80, 2261-2287, 1999.

Schmidt, A., Carslaw, K. S., Mann, G. W., Rap, A., Pringle, K. J., Spracklen, D. V., Wilson, M., and Forster, P. M.: Importance of tropospheric volcanic aerosol for indirect radiative forcing of climate, Atmos. Chem. Phys., 12, 7321-7339, doi:doi:10.5194/acp12-7321-2012, 2012. 
Spracklen, D. V., Pringle, K. J., Carslaw, K. S., Chipperfield, M. P., and Mann, G. W.: A global off-line model of size-resolved aerosol microphysics: I. Model development and prediction of aerosol properties, Atmos. Chem. Phys., 5, 2227-2252, doi:10.5194/acp-5-2227-2005, 2005.

Spracklen, D. V., Carslaw, K. S., Merikanto, J., Mann, G. W., Reddington, C. L., Pickering, S., Ogren, J. A., Andrews, E., Baltensperger, U., Weingartner, E., Boy, M., Kulmala, M., Laakso, L., Lihavainen, H., Kivekäs, N., Komppula, M., Mihalopoulos, N., Kouvarakis, G., Jennings, S. G., O’Dowd, C., Birmili, W., Wiedensohler, A., Weller, R., Gras, J., Laj, P., Sellegri, K., Bonn, B., Krejci, R., Laaksonen, A., Hamed, A., Minikin, A., Harrison, R. M., Talbot, R., and Sun, J.: Explaining global surface aerosol number concentrations in terms of primary emissions and particle formation, Atmos. Chem. Phys., 10, 4775-4793, doi:10.5194/acp-10-4775-2010, 2010.

Stefels, J., Steinke, M., Turner, S., Malin, G., and Belviso, S.: Environmental constraints on the production and removal of the climatically active gas dimethylsulphide (DMS) and implications for ecosystem modelling, Biogeochemistry, 83, 245-275, 2007.

Stier, P., Feichter, J., Kinne, S., Kloster, S., Vignati, E., Wilson, J., Ganzeveld, L., Tegen, I., Werner, M., Balkanski, Y., Schulz, M., Boucher, O., Minikin, A., and Petzold, A.: The aerosol-climate model ECHAM5-HAM, Atmos. Chem. Phys., 5, 1125-1156, doi:10.5194/acp-5-1125-2005, 2005.

Taylor, J. P., Glew, M. D., Coakley, J. A., Tahnk, W. R., Platnick, S., Hobbs, P. V., and Ferek, R. J.: Effects of aerosols on the radiative properties of clouds, J. Atmos. Sci., 57, 2656-2670, 2000.

Thomas, M. A., Suntharalingam, P., Pozzoli, L., Rast, S., Devasthale, A., Kloster, S., Feichter, J., and Lenton, T. M.: Quantification of DMS aerosol-cloud-climate interactions using the ECHAM5-HAMMOZ model in a current climate scenario, Atmos. Chem. Phys., 10, 7425-7438, doi:10.5194/acp-10-74252010, 2010.

Trenberth, K. E., Jones, P. D., Ambenje, P., Bojariu, R., Easterling, D., Klein Tank, A., Parker, D., Rahimzadeh, F., Renwick, J. A., Rusticucci, M., Soden, B., and Zhai, P.: Climate Change 2007: The Physical Science Basis. Contribution of Working Group I to the Fourth Assessment Report of the Intergovernmental Panel on Climate Change, chap. 3, Observations: Surface and Atmospheric Climate Change, Cambridge University Press, Cambridge, UK, and New York, NY, USA, 2007.

Twomey, S.: Pollution and planetary albedo, Atmos. Environ., 8, 1251-1256, 1974.

Uppala, S. M., Kallberg, P. W., Simmons, A. J., Andrae, U., Bechtold, V. D., Fiorino, M., Gibson, J. K., Haseler, J., Hernandez, A., Kelly, G. A., Li, X., Onogi, K., Saarinen, S., Sokka, N., Allan, R. P., Andersson, E., Arpe, K., Balmaseda, M. A., Beljaars, A. C. M., Van De Berg, L., Bidlot, J., Bormann, N., Caires, S., Chevallier, F., Dethof, A., Dragosavac, M., Fisher, M., Fuentes, M., Hagemann, S., Holm, E., Hoskins, B. J., Isaksen, L., Janssen, P. A. E. M., Jenne, R., McNally, A. P., Mahfouf, J. F., Morcrette, J. J., Rayner, N. A., Saunders, R. W., Simon, P., Sterl, A., Trenberth, K. E., Untch, A., Vasiljevic, D., Viterbo, P., and Woollen, J.: The ERA-40 re-analysis, Q. J. Roy. Meteorol. Soc., 131, 2961-3012, 2005.
Vallina, S. M. and Simó, R.: Strong relationship between DMS and the solar radiation dose over the global surface ocean, Science, 315, 506-508, 2007.

Vallina, S. M., Simó, R., and Manizza, M.: Weak response of oceanic dimethylsulfide to upper mixing shoaling induced by global warming, Proceedings Of The National Academy Of Sciences Of The United States Of America, 104, 16004-16009, 2007.

Wingenter, O. W., Elliot, S. M., and Blake, D. R.: New Directions: enhancing the natural sulfur cycle to slow global warming, Atmos. Environ., 41, 7373-7375, 2007.

Woodhouse, M. T., Mann, G. W., Carslaw, K. S., and Boucher, O.: New Directions: the impact of oceanic iron fertilisation on cloud condensation nuclei, Atmos. Environ., 42, 5728-5730, 2008.

Woodhouse, M. T., Carslaw, K. S., Mann, G. W., Vallina, S. M., Vogt, M., Halloran, P. R., and Boucher, O.: Low sensitivity of cloud condensation nuclei to changes in the sea-air flux of dimethyl-sulphide, Atmos. Chem. Phys., 10, 7545-7559, doi:10.5194/acp-10-7545-2010, 2010.

Yang, M., Huebert, B. J., Blomquist, B. W., Howell, S. G., Shank, L. M., McNaughton, C. S., Clarke, A. D., Hawkins, L. N., Russell, L. M., Covert, D. S., Coffman, D. J., Bates, T. S., Quinn, P. K., Zagorac, N., Bandy, A. R., de Szoeke, S. P., Zuidema, P. D., Tucker, S. C., Brewer, W. A., Benedict, K. B., and Collett, J. L.: Atmospheric sulfur cycling in the southeastern Pacific longitudinal distribution, vertical profile, and diel variability observed during VOCALS-REx, Atmos. Chem. Phys., 11, 5079-5097, doi:10.5194/acp-11-5079-2011, 2011.

Young, I. R., Zieger, S., and Babanin, A. V.: Global trends in wind speed and wave height, Science, 332, 451-455, 2011.

Yu, F. and Luo, G.: Simulation of particle size distribution with a global aerosol model: contribution of nucleation to aerosol and CCN number concentrations, Atmos. Chem. Phys., 9, 76917710, doi:10.5194/acp-9-7691-2009, 2009.

Yu, F. Q., Luo, G., Bates, T. S., Anderson, B., Clarke, A., Kapustin, V., Yantosca, R. M., Wang, Y. X., and Wu, S. L.: Spatial distributions of particle number concentrations in the global troposphere: simulations, observations, and implications for nucleation mechanisms, J. Geophys. Res.-Atmos., 115, D17205, doi:10.1029/2009JD013473, 2010. 